Article

\title{
Antiproliferative Activity of Neem Leaf Extracts Obtained by a Sequential Pressurized Liquid Extraction
}

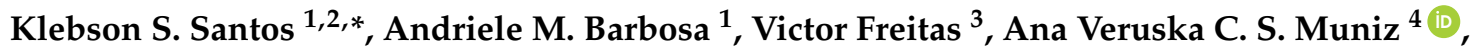 \\ Marcelo C. Mendonça ${ }^{1}$, Ricardo C. Calhelha ${ }^{5}$, Isabel C. F. R. Ferreira ${ }^{5}$ (D), Elton Franceschi ${ }^{1}$, \\ Francine F. Padilha ${ }^{1}$ (D), Maria Beatriz P. P. Oliveira ${ }^{2}$ (D) and Cláudio Dariva ${ }^{1}$ (D) \\ 1 NUESC/ITP, Program in Industrial Biotechnology-Tiradentes University, Aracaju 49032-490, Brazil; \\ andrielemendonca@yahoo.com.br (A.M.B.); marcelo_costa@unit.br (M.C.M.); \\ franceschi.elton@gmail.com (E.F.); fpadilha@yahoo.com (F.F.P.); claudio.dariva@gmail.com (C.D.) \\ 2 REQUIMTE/LAQV, Department of Chemistry Sciences, Faculty of Pharmacy, University of Porto, \\ 4050-313 Porto, Portugal; beatoliv@ff.up.pt \\ 3 Chemistry Investigation Centre (CIQ), Department of Chemistry, Faculty of Sciences, University of Porto, \\ 4169-007 Porto, Portugal; vfreitas@fc.up.pt \\ 4 Embrapa Coastal Tablelands, Aracaju 49025-040, Brazil; ana.veruska@embrapa.br \\ 5 Mountain Research Center (CIMO), School of Agriculture, Polytechnic Institute of Bragança, \\ Campus de Santa Apolónia, 5300-253 Bragança, Portugal; calhelha@ipb.pt (R.C.C.); \\ iferreira@ipb.pt (I.C.F.R.F.) \\ * Correspondence: klebson-biomedico@hotmail.com; Tel.: +55-079-3218-2153
}

Received: 13 July 2018; Accepted: 25 July 2018; Published: 30 July 2018

\begin{abstract}
Azadirachta indica A. Juss (neem) extracts have been used in pharmaceutical applications as antitumor agents, due to their terpenes and phenolic compounds. To obtain extracts from neem leaves with potential antiproliferative effect, a sequential process of pressurized liquid extraction was carried out in a fixed bed extractor at $25^{\circ} \mathrm{C}$ and 100 bar, using hexane (SH), ethyl acetate (SEA), and ethanol (SE) as solvents. Extractions using only ethanol (EE) was also conducted to compare the characteristics of the fractionated extracts. The results obtained by liquid chromatography-electrospray ionization mass spectrometry suggested a higher concentration of terpenes in the SEA extract in comparison to $\mathrm{SH}, \mathrm{SE}$, and EE extracts. Therefore, antiproliferative activity showed that SEA extracts were the most efficient inhibitor to human tumor cells MCF-7, NCI-H460, HeLa, and HepG2. Hepatocellular cells were more resistant to $\mathrm{SH}, \mathrm{SEA}, \mathrm{SE}$, and EE compared to breast, lung, hepatocellular, and cervical malignant cells. Neem fractioned extracts obtained in the present study seem to be more selective for malignant cells compared to the non-tumor cells.
\end{abstract}

Keywords: sequential pressurized liquid extraction; neem leaves; antiproliferative activity

\section{Introduction}

Neem (Azadirachta indica A. Juss) is a tree of the Meliaceae family found worldwide in semi-tropical and tropical climates [1]. The medicinal properties of the plant are related to the presence of salannin, nimbin, gedunin and nimbolide [2], among others terpenes and phenolic compounds in neem leaves extracts $[3,4]$. Neem-compounds have exhibited chemopreventive and anticancer efficacy due to their cellular and molecular mechanisms of action, such as immunomodulatory, carcinogen-detoxification, cell-cycle arrest, programmed cell death, and anti-metastatic [5]. The anticancer activity of neem constituents can inhibit the growth of a variety of human cancers, such as lung, breast, oral, prostate, skin, liver [6,7] and cervical [8]. 
Pharmacological bioactive compounds can be obtained by different extraction methods such as maceration, soxhlet, and pressurized liquid extraction (PLE) $[9,10]$. PLE shows a great potential for the extraction of metabolites from vegetable matrices [11-13] due to the possibility of using a variety of polar and non-polar solvents under high pressure, which improves the efficiency of the extraction process $[14,15]$. PLE enables extraction in a lower extraction time and using a small amount of solvent [16,17], and was also used for the exhaustive extraction of analytes in one or more clean-up steps [18]. In this sense, the PLE is considered a promising process to obtain natural compounds [11-13].

As the majority of vegetable extracts, the neem extract also is composed by a variety of chemical compounds. In this sense, depending on the characteristics of the extraction solvent used, the potential medicinal activity of the extract can also be quite distinct $[4,10]$. Hexane, ethyl acetate, and ethanol are efficient solvents used to extract terpenes and flavonoids, that are important compounds to human health $[19,20]$. The aim of this study was to develop a method to obtain extracts with antiproliferative effects from neem leaves, by using a sequential process of pressurized liquid extraction employing hexane (SH), ethyl acetate (SEA), and ethanol (EE) as solvents, and evaluate the cytotoxicity of the extracts obtained against human tumor cell lines and non-tumor liver cells.

\section{Results and Discussion}

\subsection{Pressurized Liquid Extraction Process}

Table 1 presents the average values and standard deviation of the extraction yield of neem leaves using n-hexane (SH), ethyl acetate (SEA), and ethanol (SE) as solvents in the sequential pressurized liquid extraction and the ethanolic extract solvent (EE) using the one-step pressurized liquid extraction. The results presented in Table 1 showed that increasing the solvent polarity from hexane to ethanol $(80 \%)$ leads to a significant enhancement in the dry mass (yield) obtained from neem leaves. Furthermore, SE and EE yields were not significantly different at $p<0.05$, suggesting that the previous extractions with hexane and ethyl acetate did not reduce the ethanol extractive capacity. However, either hexane and ethyl acetate showed a lower capacity to obtain a dry extract from neem leaves compared to ethanol.

Table 1. Effect of different solvents, hexane (SH), ethyl acetate (SEA), and ethanol (SE and EE) on the dry mass of neem leaves in the PLE process.

\begin{tabular}{ccc}
\hline Neem Leaves (20 g) & One-Step Extraction (g) & Three-Step Extraction (g) \\
\hline Hexane (SH) & - & $0.07 \pm 0.01^{\mathrm{b}}$ \\
Ethyl acetate (SEA) & - & $0.06 \pm 0.01^{\mathrm{b}}$ \\
Etanol 80\% (SE) & $1.58 \pm 0.26^{\mathrm{a}}$ & $1.50 \pm 0.12^{\mathrm{a}}$ \\
Etanol 80\% (EE) & -
\end{tabular}

Data are reported as mean \pm standard deviation values. Equal letters $(a$, and $b)$ indicate that there is no difference between the extractions. Not performed (_).

\subsection{Liquid Chromatography Analysis}

In this study, liquid chromatography-mass spectrometry was used for the chemical characterization of the neem leaves extracts. Figure 1 shows the PDA chromatograms of neem extracts obtained by PLE with different solvents. 

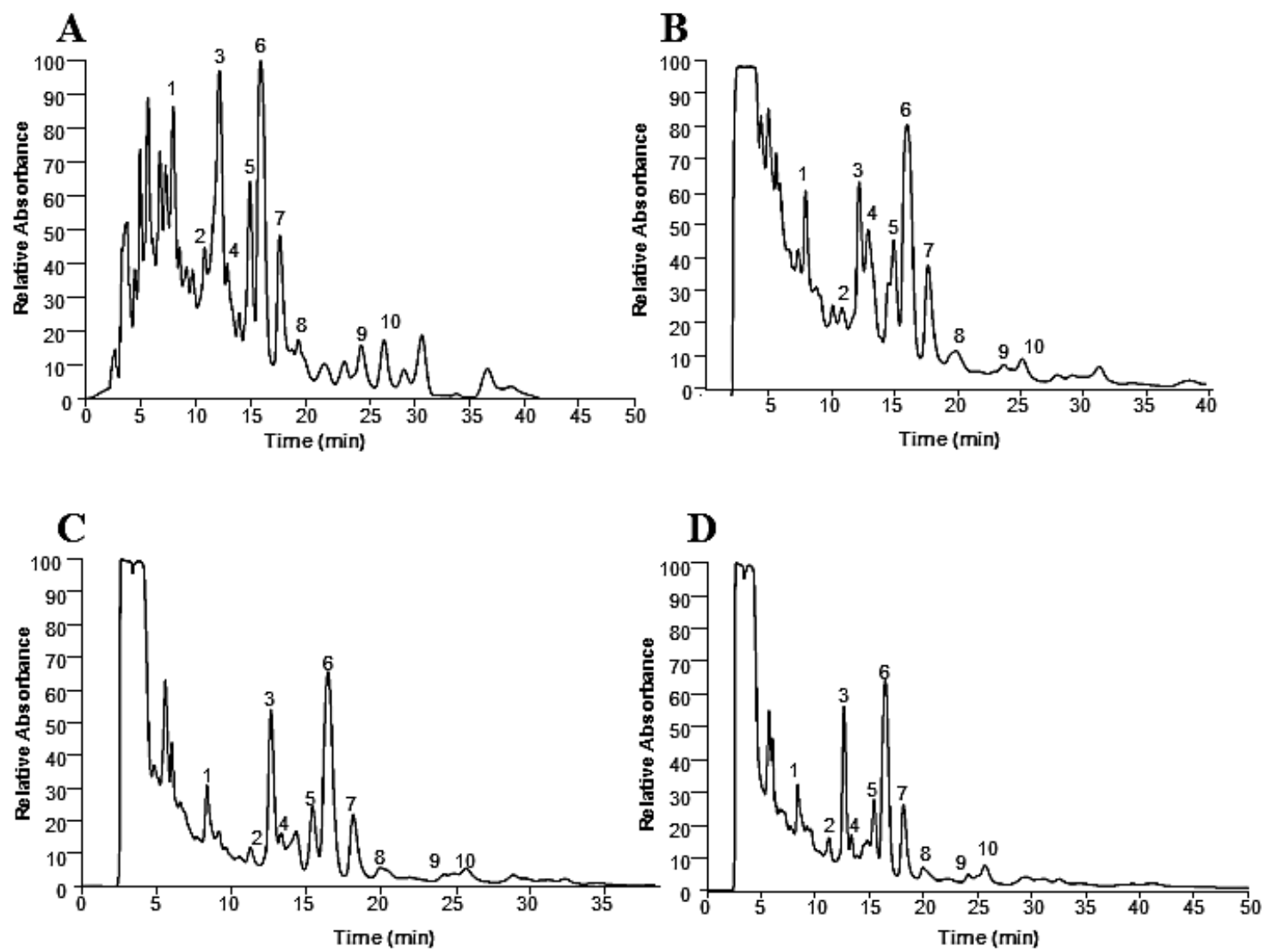

Figure 1. LC-PDA chromatograms at 210-220 nm of the neem leave extracts obtained by PLE. SH (A), SEA (B), SE (C), and EE (D).

Table 2 presents the 10 neem leaves compounds tentatively identified by ESI-MS from their fragmentation $(m / z)$, in positive mode, with the respective HPLC areas for the different extraction solvents.

Table 2. Neem leaves compounds in the PLE extracts tentatively identified by ESI-MS from their fragmentation $(m / z)$, in positive mode, and HPLC areas for the distinct extraction solvents.

\begin{tabular}{|c|c|c|c|c|c|}
\hline Extract & Peak & $t_{R}(\min )$ & Area & Compound & Observed Ions $(\mathrm{m} / \mathrm{z})$ \\
\hline $\mathrm{SH}$ & \multirow{4}{*}{1} & 8.42 & 45724118 & \multirow{4}{*}{ Nimbandiol } & \multirow{4}{*}{$\begin{array}{c}371,401,421,425,441 \\
444,457[\mathrm{M}+\mathrm{H}]^{+}, 474 \\
{\left[\mathrm{M}+\mathrm{H}_{2} \mathrm{O}\right]^{+}}\end{array}$} \\
\hline SEA & & 8.46 & 38701542 & & \\
\hline SE & & 8.56 & 20010994 & & \\
\hline $\mathrm{EE}$ & & 8.40 & 25006988 & & \\
\hline $\mathrm{SH}$ & \multirow{4}{*}{2} & 11.29 & 29873977 & \multirow{4}{*}{ 6-Deacetylnimbin } & \multirow{4}{*}{$\begin{array}{c}389,453,467,499 \\
{[\mathrm{MH}]^{+}, 516[\mathrm{M}+} \\
\left.\mathrm{H}_{2} \mathrm{O}\right]^{+}\end{array}$} \\
\hline SEA & & 11.42 & 22241890 & & \\
\hline $\mathrm{SE}$ & & 11.32 & 2818278 & & \\
\hline $\mathrm{EE}$ & & 11.46 & 14511268 & & \\
\hline $\mathrm{SH}$ & \multirow{4}{*}{3} & 12.77 & 81159631 & \multirow{4}{*}{ 2,3-Dihydronimbolide } & \multirow{4}{*}{$\begin{array}{c}178,315,426,433,441 \\
450,469[\mathrm{MH}]^{+}, 486[\mathrm{M} \\
\left.+\mathrm{H}_{2} \mathrm{O}\right]^{+}\end{array}$} \\
\hline SEA & & 12.75 & 37973099 & & \\
\hline SE & & 12.76 & 28340365 & & \\
\hline $\mathrm{EE}$ & & 12.84 & 36750310 & & \\
\hline $\mathrm{SH}$ & \multirow{4}{*}{4} & 13.91 & 13066767 & \multirow{4}{*}{ Rutin } & \multirow{4}{*}{$\begin{array}{c}266,480,546,558,611 \\
{[\mathrm{M}+\mathrm{H}]^{+}, 628[\mathrm{M}+} \\
\left.\mathrm{H}_{2} \mathrm{O}\right]^{+}\end{array}$} \\
\hline SEA & & 14.02 & 17659833 & & \\
\hline SE & & 13.95 & 14990955 & & \\
\hline $\mathrm{EE}$ & & 14.02 & 15674396 & & \\
\hline
\end{tabular}


Table 2. Cont.

\begin{tabular}{|c|c|c|c|c|c|}
\hline Extract & Peak & $t_{R}(\min )$ & Area & Compound & Observed Ions $(m / z)$ \\
\hline $\mathrm{SH}$ & \multirow{4}{*}{5} & 15.56 & 36960991 & \multirow{4}{*}{ Nimonol } & \multirow{4}{*}{$\begin{array}{c}274,293,353,421,439 \\
453[\mathrm{M}+\mathrm{H}]^{+}, 470[\mathrm{M}+ \\
\left.\mathrm{H}_{2} \mathrm{O}\right]^{+}\end{array}$} \\
\hline SEA & & 15.59 & 31070403 & & \\
\hline SE & & 15.67 & 15495619 & & \\
\hline $\mathrm{EE}$ & & 15.52 & 20995715 & & \\
\hline $\mathrm{SH}$ & \multirow{4}{*}{6} & 16.39 & 70699349 & \multirow{4}{*}{ Nimbolide } & \multirow{4}{*}{$\begin{array}{c}277,435,435,467[\mathrm{M}+ \\
\mathrm{H}]^{+}, 484\left[\mathrm{M}+\mathrm{H}_{2} \mathrm{O}\right]^{+}\end{array}$} \\
\hline SEA & & 16.54 & 86571238 & & \\
\hline SE & & 16.42 & 50917437 & & \\
\hline $\mathrm{EE}$ & & 16.45 & 57586856 & & \\
\hline $\mathrm{SH}$ & \multirow{4}{*}{6} & 16.39 & 70699349 & \multirow{4}{*}{ 3-Deacetylsalannin } & \multirow{4}{*}{$\begin{array}{c}555[\mathrm{M}+\mathrm{H}]^{+}, 572[\mathrm{M}+ \\
\left.\mathrm{H}_{2} \mathrm{O}\right]^{+}\end{array}$} \\
\hline SEA & & 16.54 & 86571238 & & \\
\hline SE & & 16.42 & 50917437 & & \\
\hline $\mathrm{EE}$ & & 16.45 & 57586856 & & \\
\hline $\mathrm{SH}$ & \multirow{4}{*}{7} & 18.22 & 32928497 & \multirow{4}{*}{ 6-Deacetylnimbinene } & \multirow{4}{*}{$\begin{array}{c}363,393,409,441[\mathrm{M}+ \\
\mathrm{H}]^{+}, 458\left[\mathrm{M}+\mathrm{H}_{2} \mathrm{O}\right]^{+}\end{array}$} \\
\hline SEA & & 18.18 & 37398457 & & \\
\hline SE & & 18.12 & 15714996 & & \\
\hline $\mathrm{EE}$ & & 18.32 & 21712675 & & \\
\hline $\mathrm{SH}$ & \multirow{4}{*}{8} & 19.88 & 15628192 & \multirow{4}{*}{ Nimbanal } & \multirow{4}{*}{$\begin{array}{c}221,265,339,345,405 \\
428,451,453,455,471 \\
482,493,511[\mathrm{M}+\mathrm{H}]^{+} \\
528\left[\mathrm{M}+\mathrm{H}_{2} \mathrm{O}\right]^{+}\end{array}$} \\
\hline SEA & & 19.93 & 23156736 & & \\
\hline SE & & 19.87 & 6245251 & & \\
\hline EE & & 19.74 & 11010022 & & \\
\hline $\mathrm{SH}$ & \multirow{4}{*}{9} & 24.96 & 14175318 & \multirow{4}{*}{ Salannin } & \multirow{4}{*}{$\begin{array}{c}199,230,278,319,378 \\
481,515,571,597[\mathrm{M}+ \\
\mathrm{H}]^{+}, 614\left[\mathrm{M}+\mathrm{H}_{2} \mathrm{O}\right]^{+}\end{array}$} \\
\hline SEA & & 24.86 & 12952957 & & \\
\hline SE & & 24.87 & 5526287 & & \\
\hline $\mathrm{EE}$ & & 24.93 & 2517812 & & \\
\hline $\mathrm{SH}$ & \multirow{4}{*}{10} & 25.49 & 17132995 & \multirow{4}{*}{ Gedunin } & \multirow{4}{*}{$\begin{array}{c}184,259,287,344,372 \\
405,425,451,483[\mathrm{M}+ \\
\mathrm{H}]^{+}, 500\left[\mathrm{M}+\mathrm{H}_{2} \mathrm{O}\right]^{+}\end{array}$} \\
\hline SEA & & 25.67 & 13462271 & & \\
\hline SE & & 25.75 & 6429235 & & \\
\hline $\mathrm{EE}$ & & 25.70 & 7359673 & & \\
\hline
\end{tabular}

It can be observed from Figure 1 and Table 2 that the compounds obtained in each extraction fraction were similar. On the other hand, the concentration of each compound was distinct related to the polarity and capacity of solvation of each solvent. Nevertheless, it should be noted that different compounds in different extracts may result in distinct antiproliferative activity. Also, distinct concentrations of biocompounds in the extracts can alter their antiproliferative potential. The compounds extracted by SH and SEA were similar, but with different relative absorbance, as could be observed in Figure 1 and Table 2. The extracts from SH and SEA are more concentrated in the compounds in comparison to SE and EE extracts. Peak 6 is the most abundant and its mass spectral analysis suggested that it corresponds to nimbolide or 3-deacetylsalannin. Figure 2 presents the mass spectra and the respective structure of these compounds.

These compounds have already been described in neem leaves [5,21-30]. Figure $1 \mathrm{~A}, \mathrm{~B}$ show a relatively higher absorbance (about 20\%) for the peaks 1, 3 and 6 . Accordingly, these solvents (hexane and ethyl acetate) have a low contribution to overall extraction yield, but a high contribution for several compounds (this is the case of 1,3 and 6). Comparing the solvents, it seems that the chemical profile of the polar solvents presents more similarity among them when compared with the non-polar one (Figure 1A).

The mass of nimbolide is 466.199 with a molecular formula $\mathrm{C}_{27} \mathrm{H}_{30} \mathrm{O}_{7}$, and the standard shows a mass spectrum $[\mathrm{M}+\mathrm{H}]^{+}$peak at $m / z 467.211$ [21]. In Figure 2, the spectral analysis shows a $[\mathrm{M}+\mathrm{H}]^{+}$peak corresponding to nimbolide in all obtained extracts. The molecular formula $\mathrm{C}_{32} \mathrm{H}_{42} \mathrm{O}_{8}$, corresponding to 3-deacetylsalannin $[\mathrm{M}+\mathrm{H}]^{+}$, has been identified in neem leaves [22]. The neem compounds identified by LC-MS show the ability to make adducts with $\mathrm{H}_{2} \mathrm{O}$, forming an additional 
fragment $[\mathrm{M}+18]^{+}$. Other fragments can result from the rupture of ester bonds from the $[\mathrm{M}+\mathrm{H}]^{+}$ species [31], thereby corroborating the identification of some compounds from Table 2.
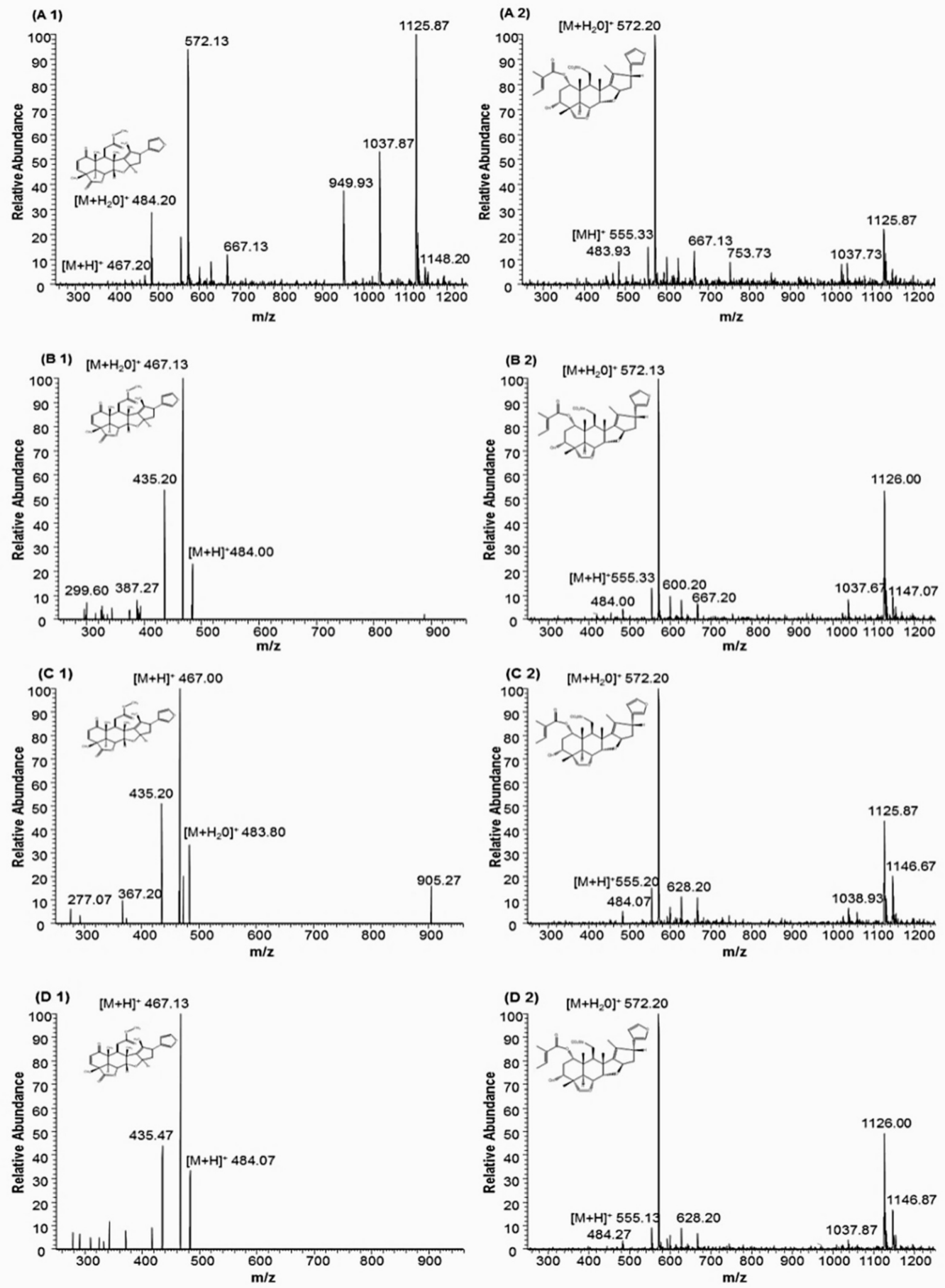

Figure 2. Mass spectra of nimbolide (A1, B1, C1, and D1) and 3-Deacetylsalannin (A2, B2, C2, and D2) terpenoids extracted by pressurized liquid extraction. Capital letters A, B, C, and D correspond to $\mathrm{SH}$, SEA, SE, and EE, respectively.

Among the 10 compounds identified in Table 1, just the compound 4 (peak 4) was not a terpene: it corresponds to rutin, a flavone $[\mathrm{M}+\mathrm{H}]^{+}$at $\mathrm{m} / \mathrm{z} 611$ [32]. However, the terpenes obtained in this study are more soluble in less-polar solvents such as n-hexane and ethyl acetate compared with the polar solvent ethanol. The affinity of the targeted compounds with the solvent used in the extraction is 
very important to obtain bioactive compounds such as anthocyanins, flavones, and terpenes $[9,33]$. According to the results, ethyl acetate (SEA) and n-hexane (SH) seem to be good options to obtain terpenes from neem leaves by sequential pressurized liquid extraction. Moreover, in this study, it was also demonstrated that the sequential extraction in fixed bed extractor cell using SEA in the second step improves the extraction of terpenes such as nimbolide and 3-deacetylsalannin, compared to the other solvents.

\subsection{Cytotoxicity Evaluation of Neem Leaves Extracts}

Neem extracts have demonstrated activity against tumor cells [14,34]. Due to the lack of studies analyzing the influence of distinct fractions of neem extracts in human tumor cells, it was investigated the antiproliferative profile of neem extracts fractions against four human tumor cells and one non-tumor cell lines. The results obtained are summarized in Table 3.

Table 3. Cytotoxicity of neem leaves extracts obtained by PLE against several human cancer cells (MCF-7, NCI-H460, HeLa, and HepG2) and the non-tumor cell (PLP2). All data $<250 \mu \mathrm{g} / \mathrm{mL}$ are reported as a mean \pm standard deviation, from growth inhibition at $50 \%\left(\mathrm{GI}_{50}\right)$.

\begin{tabular}{|c|c|c|c|c|c|}
\hline \multirow{2}{*}{ Lines } & \multicolumn{4}{|c|}{ Extract $(\mu \mathrm{g} / \mathrm{mL})$} & \multirow{2}{*}{$\begin{array}{c}\text { Control }(\mu \mathrm{g} / \mathrm{mL}) \\
\text { Ellipticine }\end{array}$} \\
\hline & SH & SEA & SE & $\mathrm{EE}$ & \\
\hline MCF-7 & $188.8 \pm 6.4^{\mathrm{a}}$ & $82.3 \pm 4.3^{b}$ & $>250^{c}$ & $>250^{c}$ & $0.9 \pm 0.1^{\mathrm{d}}$ \\
\hline NCI-H460 & $224.4 \pm 14.4^{\mathrm{a}}$ & $60.6 \pm 4.3^{b}$ & $>250^{c}$ & $>250^{c}$ & $1.0 \pm 0.1^{\mathrm{d}}$ \\
\hline HeLa & $203.9 \pm 13.6^{\mathrm{a}}$ & $48.8 \pm 4.3^{b}$ & $>250^{c}$ & $>250^{\mathrm{c}}$ & $1.9 \pm 0.1^{\mathrm{d}}$ \\
\hline HepG2 & $115.5 \pm 14.4^{\mathrm{a}}$ & $52.3 \pm 4.8^{b}$ & $>250^{c}$ & $>250^{c}$ & $1.1 \pm 0.2^{\mathrm{d}}$ \\
\hline PLP2 & $>250^{\mathrm{a}}$ & $201.3 \pm 17.0^{b}$ & $>250 \mathrm{a}$ & $>250^{a}$ & $3.2 \pm 0.7^{\mathrm{c}}$ \\
\hline
\end{tabular}

Ellipticine positive control. Equal letters $(a, b, c$, and d) in the same line indicate that there is no significant difference in the cytotoxic effects $(p<0.05)$.

As presented in Table 3, all neem extracts could inhibit the growth of human tumor cell lines. Nevertheless, these extracts exhibit different values of $\mathrm{GI}_{50}$. SEA extracts show the highest potential to inhibit the growth of tumor cells, presenting $\mathrm{GI}_{50}$ value smaller than those found for $\mathrm{SH}, \mathrm{SE}$, and EE. The result suggests that the clean-up process performed by the sequential PLE extraction was able to produce fractions with high antitumor effects. NCI-H460, HeLa, and HepG2 cells were more sensitive to SEA than the other studied cells. Some investigations have demonstrated that plant-derived fractions obtained by high pressure show an antiproliferative potential against cancer cells [35-39]. The results obtained in this study are in agreement with Hao et al., who reported that neem extracts have a potential therapeutic effect on the growth of various types of cancer cells [34].

Sharma et al., tested a vast range of concentrations $(10-500 \mu \mathrm{g} / \mathrm{mL})$ of ethanolic neem leaf extract against MCF-7 and Hela, and their GI $_{50}$ values were of $350 \mu \mathrm{g} / \mathrm{mL}$ on MCF-7 cells and $175 \mu \mathrm{g} / \mathrm{mL}$ on HeLa cells. Nevertheless, these $\mathrm{GI}_{50}$ values were higher than $\mathrm{GI}_{50}$ values found in the present study for SEA, that were $82.3 \pm 4.3 \mu \mathrm{g} / \mathrm{mL}$ and $48.8 \pm 4.3 \mu \mathrm{g} / \mathrm{mL}$ on MCF-7 and Hela, respectively. Moreover, SEA extract concentrations were also more cytotoxic to the MCF-7 and HeLa cells than 50 and $100 \mu \mathrm{g} / \mathrm{mL}$ of neem ethanolic extract combined with $5 \mu \mathrm{M}$ cisplatin (antitumor agent). According to Sharma et al., these combinations have a synergistic effect on cancer cell growth inhibition in 52.2 (MCF-7) and 65\% (HeLa) [8]. This higher antiproliferative activity exhibited by the SEA extract can be suggested due to the higher selectivity of the ethyl acetate solvent to obtain cytotoxic compounds from neem leaves. Furthermore, the 10 biocompounds obtained by the sequential process of pressurized liquid extraction may be acting in synergistic effect among them, contributing for the higher SEA extract cytotoxicity.

SEA (Table 3) also exhibits a higher cytotoxic effect against human tumor cells compared to the methanolic extracts reported by Pereira et al., who obtained GI 50 values with $83 \pm 9$ (MCF-7), $262 \pm 4$ (NCI-H460), $160 \pm 13$ (HeLa) and $100 \pm 10$ (HepG2) $\mu \mathrm{g} / \mathrm{mL}$ of Thymus vulgaris leaves and $154 \pm 7$ 
(MCF-7), $229 \pm 16$ (NCI-H460), $224 \pm 12$ (HeLa) and $111 \pm 12$ (HepG2) $\mu \mathrm{g} / \mathrm{mL}$ of Mentha x piperita leaves [40]. According to Hao et al., the antiproliferative activity of neem extract has been associated with the suppression of angiogenesis, induction of cell death, and enhancement of immune response against malignant cells [34].

Non-tumor liver PLP2 cells have been used to evaluate the tumor selectivity effect [40,41]. As can be observed in Table 3, these non-tumor cells were more resistant than the human tumor cells to the treatment with $\mathrm{SH}$, and SEA. This result can contribute to the alternative therapy development against the growth of malignant cells. Our results corroborating the Donno and co-authors finds that suggested that the phenolic and terpenic compounds from plants are biologically active substances [42].

\section{Materials and Methods}

\subsection{Neem Samples}

Young and old leaves of neem (Azadirachta indica A. Juss) were collected during the spring from Germplasm Bank (GBN) of Embrapa Coastal Tablelands (Sergipe, Brazil). All leaves were mixed and dried at $45^{\circ} \mathrm{C}$ for $36 \mathrm{~h}$ in an oven with hot-air circulation. After that, the leaves were milled and classified according to its size in the range of 8 to 16 mesh using the Tyler sieves series. The material was stored under refrigeration and protected from light until the extractions.

\subsection{Pressurized Liquid Extraction Process}

The PLE runs were performed in a $100 \mathrm{~mL}$ high-pressure extractor cell using $20 \mathrm{~g}$ of neem leaves. The extractor was constructed in stainless steel and was coupled to two high pressure pumps to the continuous displacement of high-pressure solvents. The extractor cell has a jacket and it was connected to a recirculating ultrathermostatic bath to temperature control. Pressure transducer and universal process indicators were used to monitor the extraction process variables. After inserting the neem leaves in the extractor, it was connected to the experimental unit and the first PLE step was performed at 100 bar and $25{ }^{\circ} \mathrm{C}$, using n-hexane as a solvent during $60 \mathrm{~min}$ at a flow rate of $1 \mathrm{~mL} / \mathrm{min}$. After completed this step, the flow of hexane was interrupted in the high-pressure pump, and the system was continuously flushed with carbon dioxide (around 30 bars) during 10 min to remove residual n-hexane. After that, the system was depressurized and the second PLE step was performed at 100 bar and $25^{\circ} \mathrm{C}$, using ethyl acetate as an extraction solvent for $60 \mathrm{~min}$ at $1 \mathrm{~mL} / \mathrm{min}$. The system was then flushed again with carbon dioxide during $10 \mathrm{~min}$ to remove residual ethyl acetate. The third PLE step was conducted using water/ethanol $(20: 80 \mathrm{v} / \mathrm{v})$ mixtures as solvent at $100 \mathrm{bar}, 25^{\circ} \mathrm{C}, 1 \mathrm{~mL} / \mathrm{min}$ for $60 \mathrm{~min}$ of extraction. One-step pressurized liquid extraction using water/ethanol $(20: 80 \mathrm{v} / \mathrm{v})$ mixtures as a solvent was also carried out for analyzing the effects of the sequential extraction sequential. After removing the organic solvents of the obtained solution in a rota-evaporator, the neem extracts were named SH, SEA, and SE for the sequential process using n-hexane, ethyl acetate, and water/ethanol as solvent, respectively. The one-step PLE produced an extract named EE. All extractions were performed in triplicate.

\subsection{HPLC-PDA-ESI-MS Analysis}

Liquid chromatography-mass spectrometry has been used to characterize metabolic in the pharmaceutical analysis [21]. In this study, the extracts were analyzed by HPLC-PDA-ESI-MS using a Finnigan Surveyor Plus (Finnigan Corp. San José, CA, USA) High-Performance Liquid Chromatography (HPLC) system fitted with a photodiode array (PDA, at 210-220 nm) and a liquid chromatography quaternary pump. The system was coupled to a Finnigan LCQ Deca XP max mass detector equipped with electrospray ionization source (ESI). A LIChroCART ${ }^{\circledR}$ RP-18 column $(150 \mathrm{~mm} \times 4.6 \mathrm{~mm}, 5 \mu \mathrm{m})$ (Merck Millipore, Darmstadt, Germany) was used. The mobile phase was acetonitrile/water $(60: 40 \mathrm{v} / \mathrm{v})$ at a flow rate of $0.50 \mathrm{~mL} \mathrm{~min}^{-1}$, and the runtime was $40 \mathrm{~min}$ with a sample volume injection of $25 \mu \mathrm{L}$. The mass spectrometry analysis was performed under positive 
electrospray ionization (ESI+). The mass spectra were obtained in the scan range of 250-1200 m/ $\mathrm{z}$ [21], controlled by Xcalibur software version 2.2.

\subsection{Cytotoxicity Assays}

The cell lines used were: MCF-7 (breast adenocarcinoma), NCI-H460 (non-small cell lung cancer), HeLa (cervical carcinoma), HepG2 (hepatocellular carcinoma) and PLP2 (non-tumor liver primary culture). Each cell line was grown in a 96-well microplate, at a density of $7.5 \times 10^{3}$ cells/well for MCF-7 and NCI-H460, and $1.0 \times 10^{4}$ cells/well for HeLa, HepG2, and PLP2. The cells were allowed to attach for $24 \mathrm{~h}$. After this period, distinct neem extract concentrations $(1.56-250 \mu \mathrm{g} / \mathrm{mL})$ or ellipticine (positive control) were added to the cells and incubated for $48 \mathrm{~h}$. After that, prechilled trichloroacetic acid (TCA $10 \%, 100 \mu \mathrm{L}$ ) was added and incubated for $60 \mathrm{~min}$ at $4{ }^{\circ} \mathrm{C}$ to improve the adherence of the cells. The plates were washed with deionized water, dried and after the addition of a sulforhodamine B solution (SRB $0.1 \%$ in $1 \%$ acetic acid, $100 \mu \mathrm{L}$ ), the mixture was incubated for $30 \mathrm{~min}$ at room temperature. Subsequently, the plates were washed with acetic acid (1\%) to remove the unbound SRB and dried. The bounded SRB was solubilized with Tris $(10 \mathrm{mM}, 200 \mu \mathrm{L})$ and the absorbance measured at $540 \mathrm{~nm}$ using an ELX800 microplate reader (Bio-Tek Instruments, Inc.; Winooski, VT, USA) [40,43].

\subsection{Statistical Analysis}

Statistical analysis of the results was conducted by using one-way ANOVA, followed by a post hoc Tukey's test using Prism version 5.0 software (San Diego, CA, USA). Statistical significance was concluded with $p<0.05$.

\section{Conclusions}

This study demonstrated that sequential-PLE is an efficient methodology for extraction of bioactive compounds from neem leaves. The use of three different solvents for the extraction process provides extracts with different antiproliferative potential. SEA extract was the most efficient growth inhibitor for the tumor cells, with a $\mathrm{GI}_{50}$ dose of $52.3 \pm 4.8,48.8 \pm 4.3,60.6 \pm 4.3$, and $82.3 \pm 4.3 \mu \mathrm{g} / \mathrm{mL}$ to HepG2, HeLa, NCI-H460, and MCF-7, respectively. Nevertheless, results indicated that PLP2 non-tumor cells were more resistant to all extracts obtained in the present study with a $\mathrm{GI}_{50}$ dose higher than $200 \mu \mathrm{g} / \mathrm{mL}$. The present study provides a process to obtain extracts of neem leaves with potential application as antiproliferative of malignant cells.

Author Contributions: Methodology, K.S.S., A.M.B. and R.C.C.; Formal analysis, V.F., A.V.C.S.M., R.C.C., I.C.F.R.F., E.F. and C.D., M.C.M.; Funding acquisition; Writing-Review \& Editing, K.S.S., F.F.P., M.B.P.P.O. and C.D.

Funding: This research was supported by CAPES (Brazil), FAPITEC (Brazil), CNPq (Brazil), FCT (Portugal) and FEDER (Europe).

Acknowledgments: Klebson Silva Santos thanks CAPES (Process: PDSE 99999.003409/15-5) for the financial support during his Ph.D. studies in Portugal. Authors are grateful to CAPES, and FAPITEC (EDITAL CAPES/FAPITEC N ${ }^{\circ}$ 11/2016-PROEF/Processo de AUXPE 88881.157437/2017-01) for the financial support. The study was also carried out with financial support from FEDER, under the Partnership Agreement PT2020.

Conflicts of Interest: The authors declare no conflict of interest.

\section{References}

1. Raphael, E. Phytochemical constituents of some leaves extract of Aloe vera and Azadirachta indica plant species. GARJEST 2012, 1, 14-17.

2. Hashmat, I.; Azad, H.; Ahmed, A. Neem (Azadirachta indica A. Juss)-A nature's drugstore: An overview. Int. Res. J. Biol. Sci. 2012, 1, 76-79.

3. Al-Jadidi, H.S.K.; Hossain, M.A. Studies on total phenolics, total flavonoids and antimicrobial activity from the leaves crude extracts of neem traditionally used for the treatment of cough and nausea. BJBAS 2015, 4, 93-98. 
4. Hossain, M.A.; Al-Toubi, W.A.; Weli, A.M.; Al-Riyami, Q.A.; Al-Sabahi, J.N. Identification and characterization of chemical compounds in different crude extracts from leaves of Omani neem. JTUSCI 2013, 7, 181-188. [CrossRef]

5. Patel, S.M.; Venkata, K.C.N.; Bhattacharyya, P.; Sethi, G.; Bishayee, A. Potential of neem (Azadirachta indica L.) for prevention and treatment of oncologic diseases. Sem. Cancer Biol. 2016, 40, 100-115. [CrossRef] [PubMed]

6. Dixit, S.; Ali, H. Anticancer activity of medicinal plant extract-a review. J. Chem. Chem. Sci. 2010, 1, 79-85.

7. Atawodi, S.E.; Atawodi, J.C. Azadirachta indica (neem): A plant of multiple biological and pharmacological activities. Phytoch. Rev. 2009, 8, 601-620. [CrossRef]

8. Sharma, C.; Vas, A.J.; Goala, P.; Gheewala, T.M.; Rizvi, T.A.; Hussain, A. Ethanolic Neem (Azadirachta indica) leaf extract prevents growth of MCF-7 and HeLa cells and potentiates the therapeutic index of Cisplatin. J. Oncol. 2014, 2014, 321754. [CrossRef] [PubMed]

9. Azmir, J.; Zaidul, I.; Rahman, M.; Sharif, K.; Mohamed, A.; Sahena, F.; Jahurul, M.; Ghafoor, K.; Norulaini, N.; Omar, A. Techniques for extraction of bioactive compounds from plant materials: A review. J. Food Eng. 2013, 117, 426-436. [CrossRef]

10. Sasidharan, S.; Chen, Y.; Saravanan, D.; Sundram, K.M.; Yoga Latha, L. Extraction, isolation and characterization of bioactive compounds from plants' extracts. Afr. J. Tradit. Comple. Altern. Med. 2011, 8, 1-10. [CrossRef]

11. Garmus, T.T.; Paviani, L.C.; Queiroga, C.L.; Cabral, F.A. Extraction of phenolic compounds from pepper-rosmarin (Lippia sidoides Cham.) leaves by sequential extraction in fixed bed extractor using supercritical $\mathrm{CO}_{2}$, ethanol and water as solvents. J. Supercrit. Flui. 2015, 99, 68-75. [CrossRef]

12. Monroy, Y.M.; Rodrigues, R.A.; Sartoratto, A.; Cabral, F.A. Extraction of bioactive compounds from cob and pericarp of purple corn (Zea mays L.) by sequential extraction in fixed bed extractor using supercritical $\mathrm{CO}_{2}$, ethanol, and water as solvents. J. Supercrit. Flui. 2016, 107, 250-259. [CrossRef]

13. Garmus, T.T.; Paviani, L.C.; Queiroga, C.L. Magalhães, P.M.; Cabral, F.A. Extraction of phenolic compounds from pitanga (Eugenia uniflora L.) leaves by sequential extraction in fixed bed extractor using supercritical $\mathrm{CO}_{2}$, ethanol and water as solvents. J. Supercrit. Flui. 2014, 86, 4-14. [CrossRef]

14. Ong, E.S.; Len, S.M. Pressurized hot water extraction of berberine, baicalein and glycyrrhizin in medicinal plants. Anal. Chim. Act. 2003, 482, 81-89. [CrossRef]

15. Eng, A.T.W.; Heng, M.Y.; Ong, E.S. Evaluation of surfactant assisted pressurized liquid extraction for the determination of glycyrrhizin and ephedrine in medicinal plants. Anal. Chim. Acta 2007, 583, 289-295. [CrossRef] [PubMed]

16. Smith, R.M. Extractions with superheated water. J. Chromatog. A 2002, 975, 31-46. [CrossRef]

17. Mustafa, A.; Turner, C. Pressurized liquid extraction as a green approach in food and herbal plants extraction: A review. Anal. Chim. Acta 2011, 703, 8-18. [CrossRef] [PubMed]

18. Subedi, B.; Aguilar, L.; Robinson, E.M.; Hageman, K.J.; Björklund, E.; Sheesley, R.J.; Usenko, S. Selective pressurized liquid extraction as a sample-preparation technique for persistent organic pollutants and contaminants of emerging concern. Trends Ana. Chem. 2015, 68, 119-132. [CrossRef]

19. Shirsath, S.; Sonawane, S.; Gogate, P. Intensification of extraction of natural products using ultrasonic irradiations-A review of current status. Chem. Eng. Process 2012, 53, 10-23. [CrossRef]

20. Mahapatra, S.; Young, C.Y.; Kohli, M.; Karnes, R.J.; Klee, E.W.; Holmes, M.W.; Tindall, D.J.; Donkena, K.V. Antiangiogenic effects and therapeutic targets of azadirachta indica leaf extract in endothelial cells. J. Evid. Based Complement. Alter. Med. 2012. [CrossRef] [PubMed]

21. Wu, Q.; Yuan, H.; Zhang, L.; Zhang, Y. Recent advances on multidimensional liquid chromatography-mass spectrometry for proteomics: From qualitative to quantitative analysis-A review. Anal. Chim. Acta 2012, 731, 1-10. [CrossRef] [PubMed]

22. Gika, H.G.; Theodoridis, G.A.; Plumb, R.S.; Wilson, I.D. Current practice of liquid chromatography-mass spectrometry in metabolomics and metabonomics. J. Pharm. Biomed. Anal. 2014, 87, 12-25. [CrossRef] [PubMed]

23. Haldar, S.; Mulani, F.A.; Aarthy, T.; Dandekar, D.S.; Thulasiram, H.V. Expedient preparative isolation and tandem mass spectrometric characterization of C-seco triterpenoids from Neem oil. J. Chromatogr. A 2014, 1366, 1-14. [CrossRef] [PubMed]

24. Yadav, D.K.; Bharitkar, Y.P.; Chatterjee, K.; Ghosh, M.; Mondal, N.B.; Swarnakar, S. Importance of Neem Leaf: An insight into its role in combating diseases. NISCAIR 2016, 54, 708-718.

25. Bhajoni, P.S.; Meshram, G.G.; Lahkar, M. Evaluation of the antiulcer activity of the leaves of Azadirachta indica: An experimental study. Int. Med. Int. 2016, 3, 10-16. [CrossRef] 
26. Wolfender, J.L.; Ndjoko, K.; Hostettmann, K. Liquid chromatography with ultraviolet absorbance-mass spectrometric detection and with nuclear magnetic resonance spectrometry: A powerful combination for the on-line structural investigation of plant metabolites. J. Chromatogr. A 2003, 1000, 437-455. [CrossRef]

27. Jiang, B.; Kronenberg, F.; Balick, M.; Kennelly, E. Analysis of formononetin from black cohosh (Actaea racemosa). Phytomedicine 2006, 13, 477-486. [CrossRef] [PubMed]

28. Ji, X.; Avula, B.; Khan, I.A. Quantitative and qualitative determination of six xanthones in Garcinia mangostana L. by LC-PDA and LC-ESI-MS. J. Pharm. Biomed. Anal. 2007, 43, 1270-1276. [CrossRef] [PubMed]

29. Pavei, C.; Kaiser, S.; Verza, S.G.; Borre, G.L.; Ortega, G.G. HPLC-PDA method for quinovic acid glycosides assay in Cat's claw (Uncaria tomentosa) associated with UPLC/Q-TOF-MS analysis. J. Pharm. Biomed. Anal. 2012, 62, 250-257. [CrossRef] [PubMed]

30. Zhang, Y.; Nie, M.; Shi, S.; You, Q.; Guo, J.; Liu, L. Integration of magnetic solid phase fishing and off-line two-dimensional high-performance liquid chromatography-diode array detector-mass spectrometry for screening and identification of human serum albumin binders from Radix Astragali. Food Chem. 2014, 146, 56-64. [CrossRef] [PubMed]

31. Liu, J.; Fang, Y.; Yang, L.; Qin, X.; Du, G.; Gao, X. A qualitative, and quantitative determination and pharmacokinetic study of four polyacetylenes from Radix Bupleuri by UPLC-PDA-MS. J. Pharm. Biomed. Anal. 2015, 111, 257-265. [CrossRef] [PubMed]

32. Schaaf, O.; Jarvis, A.P.; van der Esch, S.A.; Giagnacovo, G.; Oldham, N.J. Rapid and sensitive analysis of azadirachtin and related triterpenoids from neem (Azadirachta indica) by high-performance liquid chromatography-atmospheric pressure chemical ionization mass spectrometry. Chromatogr. A 2000, 886, 89-97. [CrossRef]

33. Savic, S.; Vojinovic, K.; Milenkovic, S.; Smelcerovic, A.; Lamshoeft, M.; Petronijevic, Z. Enzymatic oxidation of rutin by horseradish peroxidase: Kinetic mechanism and identification of a dimeric product by LC-Orbitrap mass spectrometry. Food Chem. 2013, 141, 4194-4199. [CrossRef] [PubMed]

34. Hao, F.; Kumar, S.; Yadav, N.; Chandra, D. Neem components as potential agents for cancer prevention and treatment. BBA Rev. Cancer 2014, 1846, 247-257. [CrossRef] [PubMed]

35. Cowan, M.M. Plant products as antimicrobial agents. Clin. Microbiol. Rev. 1999, 12, 564-582. [PubMed]

36. Sánchez-Camargo, A.; Mendiola, J.; Valdés, A.; Castro-Puyana, M.; García-Cañas, V.; Cifuentes, A.; Herrero, M.; Ibáñez, E. Supercritical antisolvent fractionation of rosemary extracts obtained by pressurized liquid extraction to enhance their antiproliferative activity. J. Supercrit. Fluid. 2016, 107, 581-589. [CrossRef]

37. Deniz, I.; Ozen, M.O.; Yesil-Celiktas, O. Supercritical fluid extraction of phycocyanin and investigation of cytotoxicity on human lung cancer cells. J. Supercrit. Fluid. 2016, 108, 13-18. [CrossRef]

38. Vicente, G.; Molina, S.; González-Vallinas, M.; García-Risco, M.R.; Fornari, T.; Reglero, G.; Molina, A.R. Supercritical rosemary extracts, their antioxidant activity and effect on hepatic tumor progression. J. Supercrit. Fluid. 2013, 79, 101-108. [CrossRef]

39. Cvetanović, A.; Švarc-Gajić, J.; Zeković, Z.; Mašković, P.; Durović, S.; Zengin, G.; Delerue-Matos, C.; Lozano-Sánchez, J.; Jakišić, A. Chemical and biological insights on aronia stems extracts obtained by different extraction techniques: From wastes to functional products. J. Supercrit. Fluid. 2017, 128, 173-181. [CrossRef]

40. Pereira, E.; Pimenta, A.I.; Calhelha, R.C.; Antonio, A.L.; Verde, S.C.; Barros, L.; Santos-Buelga, C.; Ferreira, I.C. Effects of gamma irradiation on cytotoxicity and phenolic compounds of Thymus vulgaris L. and Mentha $x$ piperita L. LWT Food Sci. Technol. 2016, 71, 370-377. [CrossRef]

41. Pereira, C.; Calhelha, R.C.; Barros, L.; Ferreira, I.C. Antioxidant properties, anti-hepatocellular carcinoma activity and hepatotoxicity of artichoke, milk thistle and borututu. Ind. Crop Prod. 2013, 49, 61-65. [CrossRef]

42. Donno, D.; Mellano, M.G.; Cerutti, A.K.; Beccaro, G.L. Biomolecules and Natural Medicine Preparations: Analysis of New Sources of Bioactive Compounds from Ribes and Rubus spp. Buds. Pharmaceuticals 2016, 9. [CrossRef] [PubMed]

43. Guimarães, R.; Barros, L.; Dueñas, M.; Calhelha, R.C.; Carvalho, A.M.; Santos-Buelga, C.; Queiroz, M.J.R.; Ferreira, I.C. Nutrients, phytochemicals and bioactivity of wild Roman chamomile: A comparison between the herb and its preparations. Food Chem. 2013, 136, 718-725. [CrossRef] [PubMed]

(C) 2018 by the authors. Licensee MDPI, Basel, Switzerland. This article is an open access article distributed under the terms and conditions of the Creative Commons Attribution (CC BY) license (http:/ / creativecommons.org/licenses/by/4.0/). 